\title{
EMPLOYING PROGRAM-TERGET METHODS IN THE FOREIGN SECTOR OF THE RUSSIAN ECONOMY
}

\author{
A.Pakhomov
}

According to economic theories, the application of program-target methods (PTMs) ${ }^{1}$ of governance and regulation at the industrial level, including the foreign sector of the economy, allows target objectives to be achieved at faster pace, with higher probability and cost-effectively.

Despite the fact that the foreign sector is technically a secondary sector of the Russian economy, it has a systemic effect on the development of the national economy as a whole through the prevailing energymineral model which is focused on exports. It is therefore essential for the Russian economy that the effectiveness of the foreign economic policy as a whole is enhanced and specific industry objectives are fulfilled.

Several attempts have been made in Russia since the second half of the 2000s to develop and implement dedicated programs in the foreign sector using program-target methods ${ }^{2}$. Initially, the introduction of respective policy documents was initiated by Belousov A. Mr. Belousov wanted to tire these documents with the concept of strategic planning in Russia ${ }^{3}$. A structured list of the principal programs which determine the development of the Russian foreign sector in 2008-2015 is presented in Table 1.

These programs have common issues of implementation despite that they cover various stages of the Russian economic development, including the precrisis stage, post-crisis stage and the current stage. Baseline approaches to the development and implementation of the programs (Klepach A., Spartak A., Aleksashenko A. at all) saw changes from time to time, although the outcome - low effectiveness of deliverables - remained the same.

Furthermore, various options of enhancing the effectiveness of the aforementioned programs have recently been proposed. For instance, Herman Gref views the issues of public administration from a strictly technocratic standpoint. The elements of a governance system, according to Mr. Gref, are com-

1 PTMs aim to link the goals of socio-economic development plans with a set of economic, social, science and technology, and industrial measures using instruments and resources which are designed for implementing the plans.

2 More details on the evolution of foreign economic policy documents in Russia are available in A. Pakhomov's article entitled "The development strategy for the foreign economy complex in the Russian Federation" / Problemy Teorii i Praktiki Upravleniya. 2010. No. 12. P. $18-29$.

3 See, for example, Belousov A. Russia's economic strategy: The transition to a long-term development governance / Problemy Teorii i Praktiki Upravleniya. 2007. No. 9. P. 8-14. prised of hard skills (engineering/technical systems, processes and skills which relate to the fulfillment of tasks) and soft skills (human skills - including leadership, management style and corporate culture - which make the process more efficient). According to expert evaluations, $85 \%$ of success is due to soft skills, whereas $15 \%$ to hard skills.

The advanced countries are currently competing with each other on a global scale, and the winners are those who invest in soft skills, i.e. the development of systemically important institutions, which also includes the development of human capital and enhancement of investment environment. Also, there are hard skills which reflect the quality of institutions, and there is a social paradigm (ideology) which is the basis of all. This is the key trend which Russia should take, according to Mr. Gref. All speculations about drastic transformation "should be reduced to a single reform; if we don't do this, then other reforms would fail or produce inadequate results"4.

Based on the criteria of the above proposed approach, the key shortcomings of using PTMs in the Russian foreign sector can be tentatively described as follows:

Hard skills - quality of institutions:

- Insufficient budget and earmarked financing;

- Low quality of industry documents (without actually using models);

- Low level of interdepartmental coordination;

- Documents fail to meet the principles specified in the Federal Law "On the Strategic Planning in the Russian Federation" dated 28 June 2014, No. 172-FZ;

Soft skills - human capital:

- Lack of external or non-governmental oversight and procedures for measuring project deliverables (effectiveness);

- There is an implementation-related gap between the "goals-objectives" and "instruments-measures" chains;

4 Gref H., "This has happened for the first time in the history of this country", Vedomosti, 27.052015 (in Russian). 
THE PRINCIPAL POLICY DOCUMENTS ON THE DEVELOPMENT OF RUSSIA'S FOREIGN SECTOR

\begin{tabular}{|c|c|c|c|}
\hline Title & Statutory instruments & $\begin{array}{c}\text { Target } \\
\text { (with regard to foreign economic policy) }\end{array}$ & $\begin{array}{l}\text { Ministries } \\
\text { and government bodies }\end{array}$ \\
\hline \multicolumn{4}{|c|}{ 2008-2010 } \\
\hline $\begin{array}{l}\text { The Concept of Long- } \\
\text { Term Socio-Economic } \\
\text { Development of the } \\
\text { Russian Federation } \\
\text { until } 2020\end{array}$ & $\begin{array}{l}\text { Russian Government } \\
\text { Executive Order } \\
\text { dated } 17 \text { November } \\
\text { 2008, No. 1662-p }\end{array}$ & $\begin{array}{l}\text { Searching for ways and means to provide, } \\
\text { in the long term, (2008-2020) a steady } \\
\text { improvement of the welfare of Russia's } \\
\text { nationals, national security, dynamic eco- } \\
\text { nomic development, strengthening Russia's } \\
\text { positions in the world community }\end{array}$ & $\begin{array}{l}\text { Ministry of Economic } \\
\text { Development, } \\
\text { federal executive power bodies }\end{array}$ \\
\hline $\begin{array}{l}\text { The Foreign Economic } \\
\text { Strategy of the Russian } \\
\text { Federation until } 2020\end{array}$ & $\begin{array}{l}\text { Approved by the } \\
\text { Russian Government } \\
\text { on } 26 \text { October } 2008\end{array}$ & $\begin{array}{l}\text { Creating conditions for Russia to occupy } \\
\text { leading positions in the global economy on } \\
\text { the basis of efficient participation in the } \\
\text { world division of labor and global competi- } \\
\text { tive power of the national economy }\end{array}$ & $\begin{array}{l}\text { Ministry of Economic } \\
\text { Development, } \\
\text { federal executive power bodies }\end{array}$ \\
\hline $\begin{array}{l}\text { The Key Focus Areas of } \\
\text { the Russian Federation } \\
\text { Government until } \\
2012 \text { (roadmaps) }\end{array}$ & $\begin{array}{l}\text { Russian Government } \\
\text { Executive Order } \\
\text { dated 17.November } \\
\text { 2009, No. 1663-p }\end{array}$ & $\begin{array}{l}\text { Move up to the level of socio-economic } \\
\text { development which fits into Russia's sta- } \\
\text { tus as a leading world power of the } 21 \text { st } \\
\text { century, occupy leading positions in global } \\
\text { economic competition and provide a reli- } \\
\text { able national security and exercise of civil } \\
\text { rights, including as part of projects: } \\
\text { - providing global competitive power } \\
\text { of manufacturing industries; } \\
\text { - integration of the Eurasian economic space }\end{array}$ & $\begin{array}{l}\text { Ministry of Economic } \\
\text { Development, } \\
\text { federal executive power bodies }\end{array}$ \\
\hline The country action plans & $\begin{array}{l}\text { Approved by the Russian } \\
\text { Government Presidium } \\
\text { on } 17 \text { March 2010, } \\
\text { Executive Orders issued } \\
\text { by the Ministry of } \\
\text { Economic Development }\end{array}$ & $\begin{array}{l}\text { Developing and implementing of most impor- } \\
\text { tant goals and priorities of the Russian foreign } \\
\text { economic policy with partner countries }\end{array}$ & $\begin{array}{l}\text { Ministry of Economic } \\
\text { Development, } \\
\text { Ministry of Foreign Affairs }\end{array}$ \\
\hline \multicolumn{4}{|c|}{$2012-2013$} \\
\hline $\begin{array}{l}\text { President Putin's Executive } \\
\text { Orders dated } 7 \text { May } 2012\end{array}$ & $\begin{array}{l}\text { Presidential Executive } \\
\text { Order dated } 7 \text { May } \\
2012 \text {, No. } 596\end{array}$ & $\begin{array}{l}\text { Improving the Doing Business rank- } \\
\text { ing for Russia from 120th in } 2011 \text { to } \\
\text { 50th in } 2015 \text { and to 20th in } 2018\end{array}$ & $\begin{array}{l}\text { Ministry of Economic } \\
\text { Development, } \\
\text { federal executive power bodies }\end{array}$ \\
\hline $\begin{array}{l}\text { The concept of creating } \\
\text { a "new image" of Trade } \\
\text { missions of the Russian } \\
\text { Federation until } 2016\end{array}$ & $\begin{array}{l}\text { Decision of the Collegium } \\
\text { of the Ministry of } \\
\text { Economic Development } \\
\text { dated } 31 \text { October } 2012\end{array}$ & $\begin{array}{l}\text { Recreating and developing the ability of Russian } \\
\text { trade missions to efficiently promote the } \\
\text { Russian economic interests in the global econ- } \\
\text { omy. This can be done by applying a customer- } \\
\text { focused approach, strengthening the HR poten- } \\
\text { tial, optimizing the geography of trade missions, } \\
\text { creating an employee motivation system }\end{array}$ & $\begin{array}{l}\text { Ministry of Economic } \\
\text { Development }\end{array}$ \\
\hline $\begin{array}{l}\text { The Agency for Strategic } \\
\text { Initiatives Road Map } \\
\text { "Support to gain access } \\
\text { to foreign markets and } \\
\text { support to exports" }\end{array}$ & $\begin{array}{l}\text { Russian Government } \\
\text { Executive Order dated } \\
\text { 29.06.2012, No. } 1128-r\end{array}$ & $\begin{array}{l}\text { Providing a successful promotion of the Russian } \\
\text { non-mineral exports in foreign markets, thereby } \\
\text { diversifying exports, increasing its contribution } \\
\text { to the modernization of the national economy, } \\
\text { providing a steady-state economic growth. }\end{array}$ & $\begin{array}{l}\text { Agency for Strategic } \\
\text { Initiatives (an autonomous } \\
\text { nonprofit organization), } \\
\text { Ministry of Economic } \\
\text { Development, } \\
\text { Ministry of Foreign Affairs, } \\
\text { Ministry of Finance, } \\
\text { Federal Customs Service, } \\
\text { Ministry of Industry and Trade, } \\
\text { federal executive power bodies }\end{array}$ \\
\hline $\begin{array}{l}\text { Strategy 2020: A new } \\
\text { model of growth - } \\
\text { new social policy }\end{array}$ & Not approved & $\begin{array}{l}\text { Strengthening Russia's position in the global } \\
\text { economy, socio-economic integration in the } \\
\text { post-Soviet space, developing relations with } \\
\text { the European Union, concluding preferen- } \\
\text { tial treaties with Asian Oceanian countries }\end{array}$ & $\begin{array}{l}\text { Ministry of Economic } \\
\text { Development, } \\
\text { Ministry of Foreign Affairs, } \\
\text { federal executive power bodies }\end{array}$ \\
\hline \multicolumn{4}{|c|}{ 2014-2015 } \\
\hline $\begin{array}{l}\text { The State Program for } \\
\text { the Development of the } \\
\text { Foreign Sector of the } \\
\text { Economy (2013-2018) }\end{array}$ & $\begin{array}{l}\text { Russian Government } \\
\text { Resolution dated } \\
15.04 .2014 \text {, No. } 330\end{array}$ & $\begin{array}{l}\text { Strengthening Russia's position in the global } \\
\text { economy, enhancing the quality parameters of } \\
\text { foreign economic policy, increasing the foreign } \\
\text { sector contribution in achieving the objec- } \\
\text { tives of modernizing the national economy }\end{array}$ & $\begin{array}{l}\text { Ministry of Economic } \\
\text { Development, } \\
\text { Ministry of Foreign Affairs, } \\
\text { Federal Customs Service, } \\
\text { Russian Border Services Agency, } \\
\text { Ministry of Industry and Trade, } \\
\text { Ministry of Finance }\end{array}$ \\
\hline
\end{tabular}


Table 1, cont'd

\begin{tabular}{|c|c|c|c|}
\hline Title & Statutory instruments & $\begin{array}{c}\text { Target } \\
\text { (with regard to foreign economic policy) }\end{array}$ & $\begin{array}{l}\text { Ministries } \\
\text { and government bodies }\end{array}$ \\
\hline $\begin{array}{l}\text { The key focus areas of the } \\
\text { customs and tariff policy } \\
\text { in } 2016 \text { and for the plan- } \\
\text { ning period of 2017-2018 }\end{array}$ & $\begin{array}{l}\text { Russian Government } \\
\text { Decision dated } \\
11 \text { June } 2015\end{array}$ & $\begin{array}{l}\text { Providing sustainable functioning of the } \\
\text { Russian economy and the member coun- } \\
\text { tries of the Eurasian Economic Union (EEU), } \\
\text { focusing on domestic points of growth }\end{array}$ & $\begin{array}{l}\text { Ministry of Economic } \\
\text { Development, } \\
\text { Ministry of Finance, } \\
\text { Federal Customs Service, } \\
\text { federal executive power bodies }\end{array}$ \\
\hline $\begin{array}{l}\text { The Russian Government } \\
\text { plan of actions aimed at } \\
\text { bringing certain Russian } \\
\text { industries in compli- } \\
\text { ance with the terms } \\
\text { of the Russia member- } \\
\text { ship in the World Trade } \\
\text { Organization (WTO) }\end{array}$ & $\begin{array}{l}\text { Minutes No. } 6 \text { of the } \\
\text { Sub-committee for } \\
\text { Economic Integration } \\
\text { dated } 18 \text { October 2012, } \\
\text { Executive Order No. } 510 \\
\text { of the Ministry of } \\
\text { Economic Development } \\
\text { dated } 25 \text { August 2014, }\end{array}$ & $\begin{array}{l}\text { Making the Russian real sector of the economy } \\
\text { be adapted to the new rules applied to the } \\
\text { WTO member states, developing measures } \\
\text { of innovative development of industrial sec- } \\
\text { tors, promoting goods, maintaining the com- } \\
\text { petitive power of domestic manufacturers } \\
\text { amid lower customs and tax protection. }\end{array}$ & $\begin{array}{l}\text { Ministry of Economic } \\
\text { Development, } \\
\text { Ministry of Foreign Affairs, } \\
\text { Ministry of Agriculture, } \\
\text { Ministry of Finance, } \\
\text { Ministry of Industry and Trade, } \\
\text { federal executive power bodies }\end{array}$ \\
\hline $\begin{array}{l}\text { The Key Focus Areas of } \\
\text { the Russian Federation } \\
\text { Government until } 2018\end{array}$ & $\begin{array}{l}\text { Approved by the } \\
\text { Russian Government } \\
\text { on } 14 \text { May } 2015\end{array}$ & $\begin{array}{l}\text { Expanding exports of goods and services, } \\
\text { increasing the share of non-mineral exports } \\
\text { to } 45 \% \text { by easing access to financial and } \\
\text { non-financial instruments of exports sup- } \\
\text { port, developing international integration }\end{array}$ & $\begin{array}{l}\text { Ministry of Economic } \\
\text { Development, } \\
\text { federal executive power bodies }\end{array}$ \\
\hline
\end{tabular}

Sources: the Russian Government official website: http://www.government.gov.ru, the Ministry of Economic Development official website: http://www.economy.gov.ru.

- Arbitrary or "in-house" target figures (indicators);

- Lack of personal responsibility of project managers;

- Formalistic performance of measures; the emphasis is placed on assignments issued by upper management, rather than on deliverables.

As a result, a stable bureaucratic system has recently been created in Russia, which is not governed by the performance-based management, rather it relies on the process-based management, when the execution of orders prevails over the achievement of goals. Furthermore, the very quality of orders/assignments has been made less important for performance measurement than their execution on so-called "milestone" dates.

The current situation reflects vividly the priority of "manual steering" at government agencies over focusing on a systemic approach which provides for the achievement of certain results, which is a framework condition for PTMs to be applied successfully.

In this context, it seems interesting to analyze foreign practices of using similar programs and project approaches. PTMs are being widely employed in the foreign sector of many countries (with a differentiated level of economic development). It is characteristic that the use of PTMs in various programs has a variety of purposes and is focused on various deliverables.

For instance, the United States in 2010-2014 implemented its National Export Initiative which was designed for doubling U.S. exports and creating 2 million new jobs. As a result, however, exports has increased as little as $24 \%$, while the plan on new jobs has been actually fulfilled. A new phase of the National Export Initiative (NEXT) has recently been launched. It is interesting to note that there is no single project financing in place and instead there are budgets of 14 departments which apply to the Congress for appropriations for the purposes of the Initiative.

The European Union is carrying out successful Crossborder Cooperation Programs between Russia and the European Union. The programs aim to develop trade and commercial relations between the EU's member countries sharing a land border or sea crossing with Russia. A total of five programs are in progress, with a total budget of more than $\mathbf{4 4 0}$ million euros. It is characteristic that this area of cooperation is not covered by sanctions.

China has the National Medium- and Long-term Program for Science and Technology Development until 2020. The program aims to create a national innovation framework, reduce (down to $30 \%$ ) the dependence on foreign technologies by, among other things, purchasing high-tech assets outside the country. A special state-owned entity (The China Investment Corporation (CIC)) was established in 2007, which has become an active player in the cross-border market of mergers and acquisitions $(M \& A)$. Originally, its budget totaled \$200bn.

Table 2 presents a comparative analysis of the specific features of using PTMs in the United States, the European Union, China and Russia. Principal instruments of non-financial and financial support to the foreign sector (FS) - including Trade Missions (Permanent Missions in the case of the EU) and banks - are used for implementing programs in all of these countries. 
APPLICATION OF PTMS IN THE FOREIGN SECTOR OF VARIOUS COUNTRIES

\begin{tabular}{|c|c|c|c|c|}
\hline & 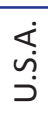 & 름 & 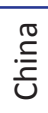 & $\frac{\pi}{\tilde{N}}$ \\
\hline $\begin{array}{l}\text { Program indicators are set } \\
\text { in statutory documents }\end{array}$ & & & & \\
\hline $\begin{array}{l}\text { The use of instruments of finan- } \\
\text { cial and banking support }\end{array}$ & & & & \\
\hline $\begin{array}{l}\text { Participation of Trade Missions } \\
\text { in the implementation of pro- } \\
\text { grams in the foreign sector }\end{array}$ & & & & \\
\hline $\begin{array}{l}\text { The existence of a single } \\
\text { agency which coordinates } \\
\text { the implementation of pro- } \\
\text { grams in the foreign sector }\end{array}$ & & & & \\
\hline $\begin{array}{l}\text { Publication of publicly- } \\
\text { available reports }\end{array}$ & & & & \\
\hline Program effectiveness analysis & & & & \\
\hline
\end{tabular}

Source: prepared by the author on the basis of the materials available in the official websites of the U.S. Department of Commerce: http://www.trade.gov, the China Ministry of Commerce: http:// www.mofcom.gov.cn, the European Commission: http://www. ec.europa.eu, the Russian Ministry of Economic Development http://www.economy.gov.ru

At the same time, for example, it is only Russia that doesn't publishes publicly-available reports on programs in progress, nor does it make analysis of the effectiveness of such programs. Indicators for programs are established by laws and regulations only in Russia and China. Both countries have a single body designed for coordination of programs, namely the Ministry of Economic Development in Russia and the Ministry of Commerce in China.

Hence one can acknowledge that the level of efficient application of PTMs in Russia is determined mainly by the quality of human capital and the management system at the departmental level. The overall effect of using project-based approaches on the Russian foreign sector remains neutral, i.e. there is no particular adverse or positive effect in general. At the same time, despite positive projections of 2013$2014^{1}$, the state of the Russian foreign sector has been deteriorating. Thus drastic measures are required to remediate the current situation.

The Russian government in the middle of July 2015 decided to create a workgroup to prepare a draft Socio-economic Development Strategy of the Russian Federation until 2030. It seems necessary to rely upon the provisions of the Federal Law "On Strategic Planning" so that this document can be drafted successfully, draw appropriately on good foreign practices of using PTMs in the foreign sector, yet the main issue of enhancing the quality of institutions remains the same.

1 See Makarov A., Pakhomov A. The deliverables of the world trading in goods and services in 2013. / Economicheskoye Razvitiye Rossii. 2014. Vol. 21, No. 5, P. 22-29.

2 "Industry documents of the Russian Federation strategic planning are developed for a period which is not longer than the period for which the long-term forecast for socio-economic development of the Russian Federation is developed, by the decision of the Russian President or the Russian government within their jurisdiction by federal executive power bodies with a view to carrying out the socio-economic development strategy of the Russian Federation, the Russian Federation national security strategy, the spatial development strategy of Russian Federation with consideration for the forecast for science and technology development in the Russian Federation, the Russian Federation strategic forecast, the long-term forecast for socio-economic development of the Russian Federation". Article 19.1 of the Federal Law "On the Strategic Planning in the Russian Federation" of 28 June 2014, No. 172-FZ. 